\title{
MASS SPECTROMETRY ANALYSIS OF SURFACE TENSION REDUCING SUBSTANCES PRODUCED BY A PAH-DEGRADING PSEUDOMONAS CITRONELLOLIS STRAIN
}

\author{
Rodrigo J. S. Jacques ${ }^{1}$; Eder C. Santos ${ }^{2}$; Renato Haddad ${ }^{3}$; Rodrigo R. Catharino ${ }^{3}$; Marcos N. Eberlin ${ }^{3}$; \\ Fátima M. Bento ${ }^{4}$; Flávio A. de Oliveira Camargo ${ }^{5 *}$
}

\begin{abstract}
${ }^{1}$ Universidade Federal do Pampa, Centro de Ciências Rurais, São Gabriel, RS, Brasil; ${ }^{2}$ Universidade Estadual de Campinas, Faculdade de Engenharia de Alimentos, Campinas, SP, Brasil; ${ }^{3}$ Universidade Estadual de Campinas, Instituto de Química, Campinas, SP, Brasil; ${ }^{4}$ Universidade Federal do Rio Grande do Sul, Departamento de Microbiologia, Porto Alegre, RS, Brasil; ${ }^{5}$ Universidade Federal do Rio Grande do Sul, Departamento de Solos, Porto Alegre, RS, Brasil.
\end{abstract}

Submitted: October 17, 2007; Returned to authors for corrections: November 23, 2007; Approved: April 25, 2008.

\begin{abstract}
In this work we investigated the structure of the iron-stimulated surface tension reducing substances produced by $P$. citronellolis $222 \mathrm{~A}$ isolated from a 17 -years old landfarming used for sludge treatment in petrochemical industries and oil refinery. Its mass spectrum differs from $P$. aeruginosa spectrum, indicating that the surface tension reducing substances produced by $P$. citronellolis can be a new kind of biosurfactant.
\end{abstract}

Key words: Pseudomonas aeruginosa, rhamnolipid mixture, ESI mass spectrum, biosurfactant

We have recently reported a bacterial isolate Pseudomonas citronellolis $222 \mathrm{~A}$ as a polycyclic aromatic hydrocarbon (PAH)degrading bacteria and biosurfactant producer (6). This bacterium belongs to the Pseudomonas aeruginosa group, from the Pseudomonadaceae family and it was initially reported by Seubert (12) as an isoprenoid-degrading bacterium. More recently, $P$. citronellolis was isolated from soil as a hydrocarbon-degrading bacterial strain, which metabolizes citronellol (isoprenoid) and can also degrade the toxic hydrocarbon constituents present in oily sludge (3). In a further study we reported that $P$. citronellolis $222 \mathrm{~A}$ showed the highest reduction of surface tension as compared with $P$. aeruginosa isolates and the addition of a soluble source of iron decreased surface tension (11). $P$. citronellolis $222 \mathrm{~A}$ isolate showed a direct dependence on iron to stimulate surface tension reducing substances production that increased anthracene biodegradation (11). For Bacillus subtilis, Wei and Chu (13) reported that supplementation of iron enabled overproduction of a biosurfactant surfactin and increased biomass growth of this bacterium in a dose dependent manner. More recently, Wei et al. (14) verified addition of iron sulfate increased markedly surfactin production initially, but further iron addition led to a decrease in the concentration of surfactin, most likely due to acidification of the culture and consequent precipitation of surfactin. To our knowledge, the work of Santos et al., (11) showing the effect of iron on surfactant production by a Pseudomonas citronellolis was firstly reported on the literature. Despite that $P$. citronellolis belongs to the Pseudomonas aeruginosa group, we are considering the presence of a different surfactant structure as compared to the rhamnolipid produced by $P$. aeruginosa sp. In this work, we did the investigation on the structure of the iron-stimulated surface tension reducing substances produced by $P$. citronellolis $222 \mathrm{~A}$ as compared to the structure of rhamolipid produced by $P$. aeruginosa LBI isolated from a petroleum-contaminated soil.

Pseudomonas citronellolis (isolate 222A) is a PAHdegrading bacteria and biosurfactant producer identified by 16S rRNA gene sequencing by Jacques et al. (6). It was isolated from 17-years old soil that was used for sludge treatment from petrochemical industries and oil refinery. P. aeruginosa LBI was isolated from petroleum-contaminated soil as previously characterized by Benincasa et al. (1) and its surfactant was used for structure comparison. For surfactant production, the isolate $222 \mathrm{~A}$ was inoculated with an initial population of $2.0 \pm 0.2$ $\log$ CFU mL ${ }^{-1}$ in mineral medium (MM) $(50 \mathrm{~mL})$ as described by Jacques et al. (6), containing $250 \mathrm{mg} \mathrm{L}^{-1}$ of anthracene (three replicates) in the absence (control) and presence of $0.1 \mathrm{mM}$

*Corresponding Author. Mailing address: Av. Bento Gonçalves, 7712, Caixa Postal 15.100, CEP 91.540-000. Porto Alegre, RS. E-mail: fcamargo@ufrgs.br 
$\mathrm{Fe}\left(\mathrm{NO}_{3}\right)_{3}$ and incubated at $30^{\circ} \mathrm{C}$ for 48 days with orbital shaking $(150 \mathrm{rpm})$. Surfactant production was estimated by the emulsification index and by the reduction of the surface tension. Emulsification evaluation was performed by the presence and absence of cells into the MM (cells were removed by centrifugation at $10,000 \mathrm{rpm}$ by $30 \mathrm{~min}$, at $4^{\circ} \mathrm{C}$ ). Two $\mathrm{mL}$ of MM were mixed with diesel oil in a pirex glass tube $(100 \mathrm{~mm} \times 15 \mathrm{~mm})$ using a vortex for 2 minutes. After that, the tubes were kept resting for 24 hours and then the volume and the stability of the emulsion were measured. The surface tension of the MM was measured in the absence of cells after samples equilibration $(1 \mathrm{~h}$ at $25^{\circ} \mathrm{C}$ ), using a model Lecont Du Nouy tensiometer. Sterile mineral medium was used as control $\left(69.2 \mathrm{mM} \mathrm{m}^{-1}\right)$. Surface tension reducing substances were extracted from culture media after cell removal by centrifugation at $8000 \mathrm{rpm}$ for $20 \mathrm{~min}$. The supernatant $\mathrm{pH}$ was adjusted to 2.0 with $6 \mathrm{~N} \mathrm{H}_{2} \mathrm{SO}_{4}$, and an equal volume of $\mathrm{CHCl}_{3} / \mathrm{CH}_{3} \mathrm{OH}$ (2:1) was added. The mixture was vigorously shaken for $5 \mathrm{~min}$ and allowed to set until phase separation. The organic phase was removed and the operation was repeated. The extracted product was concentrated from the pooled organic phases using a rotary evaporator. The viscous yellowish product obtained was dissolved in methanol and concentrated again by evaporation of the solvent at $45^{\circ} \mathrm{C}$, according to Costa et al. (4). Electrospray ionization (ESI) mass spectra were recorded on a high-resolution Q-Tof (Micromass, U.K.) mass spectrometer with a quadrupole (Qq) orthogonal time-of-flight configuration using operating conditions described in details elsewhere (4). The ESI mass spectrum in the negative ion mode was acquired using a capillary voltage of $-3.5 \mathrm{kV}$, a cone voltage of $35 \mathrm{~V}$ and desolvatation gas (nitrogen) was heated to $100^{\circ} \mathrm{C}$. ESI tandem mass spectra were acquired by mass-selecting the target ion using the quadrupole mass analyzer followed by $25 \mathrm{eV}$, collision induced dissociation using nitrogen in collision cell. The material was dissolved in methanol: water $(1: 1 \mathrm{v} / \mathrm{v})$, filtered $(0.22 \mathrm{~mm})$ and introduced into the source at $15 \mathrm{ml} \mathrm{min}^{-1}$ with a syringe pump.

After 48 days of incubation into mineral medium containing $250 \mathrm{mg} \mathrm{L}^{-1}$ of anthracene P. citronellolis $222 \mathrm{~A}$ isolate reduced surface tension from 69.2 to $36.2 \mathrm{mM} \mathrm{m}^{-1}$. Addition of $0.1 \mathrm{mM}$ of $\mathrm{Fe}-\mathrm{Fe}\left(\mathrm{NO}_{3}\right)_{3}$ to the medium increased the reduction of surface tension to $26.0 \mathrm{mM} \mathrm{m}^{-1}$, as reported by Santos et al. (11), being one of the smallest values reported in the literature, only compared to the surfactin produced by $B$. subtilis (14). This reduction was associated to the increase of the anthracene availability and consequently, increase of anthracene degradation (28\%) estimated by gas chromatography (CG-MS), as compared with the result in the absence of iron. Beyond anthracene, iron addition at $0.1 \mathrm{mM} \mathrm{Fe}\left(\mathrm{NO}_{3}\right)_{3}$ increased the growth of the P. citronellolis $222 \mathrm{~A}$ isolate living into a medium containing pyrene, phenantrene, gasoline and diesel oil. Emulsification was not detected in our work, indicating that the $P$. citronellolis $222 \mathrm{~A}$ do not produce high molecular weight surfactant as a bioemulsificant.
Mass spectroscopy analysis of the rhamnolipid produced by $P$. aeruginosa LBI yielded an ESI mass spectrum with a predominant peak at $\mathrm{m} / \mathrm{z} 649$ and a second major component at $\mathrm{m} / \mathrm{z} 503$, which corresponds to the deprotonated molecules [M$\mathrm{H}]^{-}$of the dirhamnolipid $\left(\mathrm{Rha}_{2} \mathrm{C}_{10} \mathrm{C}_{10}\right)$ and the monorhamnolipid $\left(\mathrm{RhaC}_{10} \mathrm{C}_{10}\right)$, respectively (Figure 1A). These are biosurfactants frequently produced by $P$. aeruginos $a$ and more studied and found in literature $(1,4,5,8)$. In fact, ESI-MS detected a rhamnolipid mixture produced by this Pseudomonas with the presence of other components $(\mathrm{m} / \mathrm{z} 621, \mathrm{~m} / \mathrm{z}$ 677) (Fig. 1A). Pseudo-molecular ions above 621 probably represent fragments of the molecules of monorhamnolipids and dirhamnolipid (9).P. aeruginosa frequently produce a mixture of biosurfactants. Déziel et al. (5) identified the presence of the 21 types of rhamnolipids when $P$. aeruginosa 57RP grew using mannitol as unique source of carbon.

In our work, the same situation was observed with $P$. citronellolis 222A which also produced a mixture of substances with surface tension reducing proprieties (Fig. 1B). The substances extraction was not possible in the presence of iron, probably due to some chemical interference on extraction. In the absence of iron, the ESI-MS analysis of the reducing surface tension substances mixtures produced by $P$. citronellolis $222 \mathrm{~A}$ revealed compounds of small $\mathrm{m} / \mathrm{z}$. The major component was pseudo-molecular ions at $\mathrm{m} / \mathrm{z} 341$ and two higher peaks detected as the anions of $m / z 339$ and 255; this indicates a production of components differents of $P$. aeruginosa pattern. Microorganisms synthesize a wide variety of low-molecular-mass biosurfactants (10). They are mainly rhamnolipids, trehaloselipids, sophorolipids, viscosin, surfactin, gramicidins, polymyxins, serrawettin, lipopeptides (10). However, bacterial cells can produce a large variety of surface tension reducing substances such as peptides, fatty acids, phospholipids and also antibiotics, that have low molecular mass than the named low-molecularmass biosurfactants (7). In the ESI mass spectrum produced by P. citronellolis $222 \mathrm{~A}$ it is possible to find structures similar to rhamnolipids produced by $P$. aeruginosa, as the anion of $\mathrm{m} / \mathrm{z}$ 311 corresponds to a molecule with two rhamnoses $\left(\mathrm{Rha}_{2}\right)$ could indicate a production of dirhamnolipids by P. citronellolis (2).

Variations in the chemical structure of biosurfactants have been reported by several authors $(1,7,10)$. These variations are obviously associated to species of bacteria that produce the biosurfactant, as well as variations in analytical methodologies used to characterize the molecules and growth conditions $(5,9)$. Deziel et al. (5) show that the rhamnolipids produced by $P$. aeruginosa 57RP differs both in quantity and in structure depending on if the carbon source in mineral medium was mannitol or naphthalene. The most of the works in the literature use glycerol or vegetable oils (soybean, olive, sunflower, corn) as unique source of carbon to grow biosurfactant-producing microorganisms. To our knowledge, this is the first report about the structural characterization of surface tension reducing 


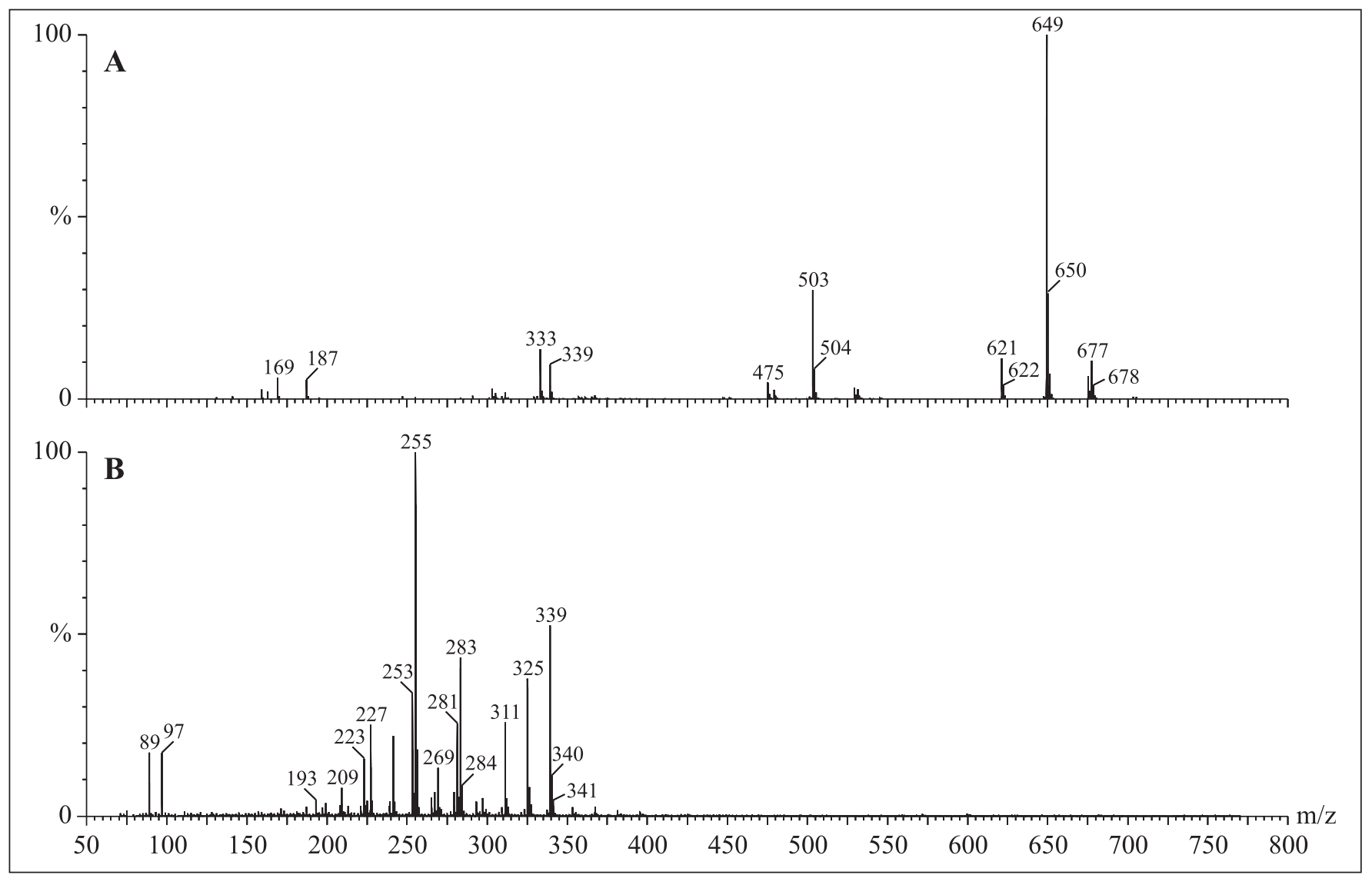

Figure 1. ESI mass spectrum for the rhamnolipids mixture produced by $P$. aeruginosa LBI (A) and the reducing surface tension substances produced by $P$. citronellolis $222 \mathrm{~A}$ (B).

substances produced in anthracene. This in part could explain the differences between ESI mass spectrum of $P$. aeruginosa and $P$. citronellolis. It was observed that surface tension reducing substances produced by $P$. citronellolis structurally seem to be different of typical rhamnolipids produced by $P$. aeruginosa, which indicates the necessity of new studies (nuclear magnetic resonance, for example) aiming to identify completely the structures of these substances, which can be a new kind of biosurfactant.

\section{RESUMO}

\section{Análise por espectrometria de massa de substâncias redutoras da tensão superficial produzidas por uma cepa de Pseudomonas citronellolis degradadora de hidrocarbonetos aromáticos policíclicos}

Neste trabalho é apresentado um estudo a respeito da análise da estrutura de substâncias redutoras de tensão superficial produzidas por Pseudomonas citronellolis 222A estimulado pela presença de ferro. Esta bactéria foi isolada de um solo que há 17 anos vem sendo utilizado para o tratamento de borra oleosa proveniente da indústria petroquímica e de refinaria de petróleo. O espectro de massa difere do espectro de $P$. aeruginosa, indicando que as substâncias redutoras de tensão superficial produzidas por $P$. citronellolis podem ser um novo tipo de biosurfactante.

Palavras-Chaves: Pseudomonas aeruginosa, mistura ramnolipídica, espectro de massa ESI, biossurfactante

\section{REFERENCES}

1. Benincasa, M.; Abalos, A.; Moreira, I.; Manresa, A. (2002). Rhamnolipid production by Pseudomonas aeruginosa LBI growing on soapstock as the sole carbon source. J. Food. Eng., 54, 283288.

2. Benincasa, M.; Abalos, A.; Moreira, I.; Manresa, A. (2004). Chemical structure, surface properties and biological activities of the biosurfactant produced by Pseudomonas aeruginosa LBI from soapstock. Antonie Leeuwenhoek, 85, 1-8. 
3. Bhattacharya, D.; Sarma, P.M.; Krishnan, S.; Mishra, S.; Lal, B. (2003). Evaluation of genetic diversity among Pseudomonas citronellolis strains isolated from oily sludge-contaminated sites. Appl. Environ. Microbiol., 69, 1435-1441.

4. Costa, S.G.V.A.O.; Nitschke, M.; Haddad, R.; Eberlin, M.N.; Contiero, J. (2006). Production of Pseudomonas aeruginosa LBI rhamnolipids following growth on Brazilian native oils. Process. Bioch., 41, 483488 .

5. Deziel, E.; Lepine, F.; Dennie, D.; Boismenu, D.; Mamer, O.A.; Villemur, R. (1999). Liquid chromatography/mass spectrometry analysis of mixtures of rhamnolipids produced by Pseudomonans aeruginosa strain 57RP grown on mannitol or naphthalene. Bioch. Biophys. Acta, 1440, 244-252.

6. Jacques, R.J.S.; Santos, E.C.; Bento, F.M.; Peralba, M.C.R.; Selbach, P.A.; Sá, E.L.S.; Camargo, F.A.O. (2005). Anthracene biodegradation by Pseudomonas sp. isolated from a petrochemical sludge landfarming. Int. Biodeg. Biodet., 56, 143-156.

7. Karanth, N.G.K.; Deo, P.G.; Veenanadig, N.K. (1999). Microbial production of biosurfactants and their importance. Curr. Sci., 77, 116-126.

8. Mata-Sandoval, J.C.; Karns, J.; Torrents, A. (1999). Highperformance liquid chromatography method for the characterization of rhamnolipid mixture produced by Pseudomonans aeruginosa UG2 on corn oil. J. Chromat., 864, 211-220.

9. Monteiro, S.A.; Sassaki, G.L.; Souza , L.M.; Meira, J.A.; Araújo, J.M.; Mitchell, D.A.; Ramos, L.P.; Krieger, N. (2007). Molecular and structural characterization of the biosurfactant produced by Pseudomonas aeruginosa DAUPE614. Chem. Phys. Lipids., 174, 1-13.

10. Rosenberg, E.; Ron, E.Z. (1999). High and low-molecular mass microbial surfactants. Appl. Microb. Biotech., 52, 154-162.

11. Santos, E.C.; Jacques, R.J.S.; Bento, F.M.; Peralba, M.C.R.; Selbach, P.A.; Sá, E.L.S.; Camargo, F.A.O. (2008). Anthracene degradation and surfactant activity by an iron-stimulated Pseudomonas sp. Biores. Technol., 99, 2644-2649.

12. Seubert, W. (1960). Degradation of isoprenoid compounds by microorganisms. I. Isolation and characterization of an isoprenoiddegrading bacterium, Pseudomonas citronellolis n. sp. J. Bacteriol., 79, 426-434.

13. Wei, Y.H.; Chu, I.M. (1998). Enhancement of surfactin production in iron-enriched media by Bacillus subtilis. Enz. Microbiol. Technol,. 22, 724-728.

14. Wei, Y.H.; Wang, L.F.; Chang, J.S.; Kung, S.S. (2003). Identification of induced acidification in iron-enriched cultures of Bacillus subtilis during biosurfactant fermentation. J. Biosc. Bioeng., 96, 174-178. 